\title{
Mystery and Contingency in Correctional Education
}

\author{
by G. WALKER \\ Virginia Commonwealth University
}

\begin{abstract}
Citing the work of Maxine Greene, Maurice Merleau-Ponty, and Thom Gehring, this paper makes the argument that correctional educators attempt to accept that they will never fully understand the lives and perspectives of their students. Noting that some of the questions correctional educators have about the lived experiences of incarcerated and formerly incarcerated students cannot be answered in a way that is fully comprehensible to those who have not lived as prisoners, the paper suggests that developing comfort with mystery will allow educators to focus on instruction.
\end{abstract}

Key words: correctional education; reentry; phenomenology; Maxine Greene; Maurice Merleau-Ponty; Thom Gehring

The City of San Bernardino, California, is similar to, and yet rather unlike, many other impoverished cities in the United States. The high cost of living in southern California presses those with less wealth east, up against the wall of the San Bernardino Mountains. Residential regulations for former offenders in nearby cities, and southern California's automobile-centric infrastructure, mean that many San Bernardino residents do not have the option of living elsewhere in the region. Taking on more than its share of southern California's formerly incarcerated, unemployed, and recovering addict population, coupled with the city's financial struggles, gives the community an air of grungy desperation.

The city is not desolate, however. It is a vibrant home to many. It throbs with life. Unlike other cities in a time of economic downturn, whose centers are forgotten and whose houses stand empty, many people continue to live bustling lives in San Bernardino. While some fled from San Bernardino during its hard times, others fled to San Bernardino, to occupy the spaces that opened for them there: living with family members in houses and apartments that would not be affordable in other parts of southern California; residing in motel rooms, in homeless shelters, or half-way houses; and sleeping in public parks or the doorways of commercial buildings.

Weiss (2006) observed the ways that homes become the foundation of our identities. When we have a home that we can take pride in, we nurture it and improve upon it, and in that process build up our sense of ourselves. Weiss wrote that "the city itself takes the place of a home" for the homeless and those in transition. If our home is disordered, we feel ungrounded. If our home is not a house, but instead the open expanse of the city, then the unpredictability of the city becomes part of our identity.

Those who make their homes in a transitional state-those who sleep outdoors, those who live in motels, or the formerly incarcerated reentering society via shelters and half-way houses-live in the "in-between" (Grosz, cited in Weiss, 2006). The in-between is a literal and psychological liminal space with few certainties. Just as life without a physical residence disrupts one's sense of self, a life without the routine of employment, a life in which you are separated from your loved ones, or a life in which drugs or mental illness isolate you from the shared world of others, the in-between makes the promise of an objective reality ring false.

The sense of the in-between should not be unfamiliar to those working in corrections and reentry. The incarcerated certainly live in a literal in-between state, in which their own future and the future of their families 
is unknown. But teachers in correctional and reentry settings face the in-between as well. Wright (2008) has described the correctional educator as a "stranger," residing in the "borderlands" between the representatives of the correctional system and their incarcerated students. Yantz (2008) examined the identity struggles of correctional educators, who often feel "lost" in the prison culture, yet separated from the culture of teachers on the outside.

Many of us who work in correctional and reentry education seek to bridge this borderland area, to make ourselves and our students feel less strange to one another. And, as we spend more time in correctional classrooms, this feeling of strangeness lessens. However, it never fully goes away. The lives of our students will always be somewhat foreign to us.

There are some near-exceptions to this, of course. Thom Gehring wrote about the work of Thomas Mott Osborne, an American prison reformer at the turn of the $20^{\text {th }}$ century who went undercover as an inmate at Auburn Prison in New York. Columbia professor Kathy Boudin (1993) served 22 years at Bedford Correctional Facility, continuing to teach and write during her sentence. Several former students at California State University's San Bernardino Reentry Initiative (CSRI) have been hired in the reentry field, including positions at CSRI, and their experiences build a vital empathetic bridge over the borderlands.

It makes sense that we would crave knowing the lived experiences of our students. However, it's important to keep in mind that the lived experiences of another person — of any person — can never be fully known to us any more than we can simultaneously see ahead and behind us. Merleau-Ponty (1962) wrote,

My human gaze never posits more than one facet of the object, even though by means of horizons it is directed towards all the others. It can never come up against previous appearances or those presented to other people otherwise than through the intermediary of time and language. If I conceive in the image of my own gaze those others which, converging from all directions, explore every corner of the [object] and define it, I have still only a harmonious and indefinite set of views of the object, but not the object in its plenitude (p. 80).

When we think about the experience of teaching in a correctional or reentry setting, we summon up our "harmonious and indefinite set of views" about our teaching environment, but we do not experience the environment "in its plenitude" any more than our students experience the correctional classroom from our perspective. We can consider different views of our classrooms based on our memories or by the descriptions of others ("It can never come up against previous appearances or those presented to other people otherwise than through the intermediary of time and language,") but we will never see more than one "facet” of our classroom at once.

For example, consider the following anecdote: two students get off a bus in front of an office park in southern California. They don't know each other, but they're headed to the same destination: the CSRI facility in the City of San Bernardino. One carries a backpack with a laptop, a water bottle, and clean clothes, while the other pulls a laundry cart filled with various items. In the parking lot in front of the CSRI, employees and students are grilling hotdogs and chatting. The newly arriving students are greeted and given bacon-wrapped hotdogs, a southern California delicacy.

We know that the bus trip, the walk, and the parking-lot cook-out was not the same perceived experience for the graduate student visiting California from the east coast as it was for the San Bernardino resident who carted their worldly possessions from bus stop to bus stop all over the city. But how different were these experiences? The fact is, we can never know.

Thom Gehring (2016) who, along with Carolyn Eggleston, founded the CSRI in 2011, provided another anecdote to illustrate the liminal, in-between-ness of correctional and reentry education. Though it serves the official function of a day reporting center for parolees, the CSRI is organized as a school and its operations revolve around classes (for example, GED, ESOL, job skills, and violence prevention are some of the many classes offered through the CSRI's programs). As a school, the CSRI holds elections for a student government and, to the extent that it's possible, the student government manages student life at the CSRI. Gehring (201) recalled a burglary that occurred soon after the CSRI first opened that resulted in the loss of some computer equipment. Gehring said that "five weeks after the event, the elected government leaders had a closed door meeting with a student [...] The next day that student told the director that he need to leave the CSRI; his pa- 
pers were processed without inquiry, and there have been no break-ins or burglaries since” (p. 115).

According to Gehring, this incident demonstrated the inevitable mystery of working in reentry facilities. The CSRI's elected student government brings those involved with the CSRI, but who have not been incarcerated, closer to an understanding of how students experience the CSRI and other programs for former inmates. However, for correctional educators and staff, there will always be a mysterious dimension to the interactions and experiences of their students. What happened in that closed-door meeting is a mystery to Gehring; most interesting of all, though, is Gehring's comfort with not knowing.

“There is a certain mystery about the CSRI and its workings [...] I do not pretend to understand it," Gehring (2016, p. 114) noted, observing that Thomas Mott Osborne wrote of a similar experience in 1924. Osborne had reorganized the US Naval Prison in Portsmouth, New Hampshire in a way that permitted the inmates to move about the prison campus freely. When asked why the prisoners willingly returned to their cells in the evening instead of escaping, Osborne said, “I don't understand it [...] I’ve been trying to understand it for six years - ever since I got into this prison game; and I haven’t succeeded yet. However, don't let it worry you; it is not necessary that either of us should understand it” (quoted in Gehring, 2016, p. 95).

Of course, this concept is nothing new in the field of education. Maxine Greene (1995) made the exploration of mystery and the unknown in the context of teaching the focus of her life's work. Asking educators to consider "the experiences of absurdity we live through when our deepest existential questions are met with blank silences” (p. 51), Greene reminded us of Merleau-Ponty's observation that we can never have a complete view of the world. We may "desire [an] all-encompassing explanation" (p. 193) of the world and its troubles, but that explanation is unlikely to come, and in the meantime, we have to carry on.

Many teachers and educational researchers feel that mystery is something that should be eradicated. Facts count; passing GED scores and low recidivism rates keep programs funded. But the in-between will always remain. We reside in it the same way the homeless reside in the city; it's complicated and it makes us feel ungrounded. However, this liminality can also be a source of inspiration in our teaching. Gehring said, "I am fueled by the anomalies" (personal communication, August 2015). Openly considering the mysteries we encounter in our lives and the lives of our students without searching for an answer, solution, or data point can bring a rich dimension to our classrooms. We may find that being open to the unknown and the in-between facilitates the very understanding of our students that we can't manage to find when we labor so hard in hopes of seeing it.

\section{References}

Boudin, K. (1993). AIDS opens the door. Harvard Educational Review, 63(2), 207-233.

DOI: http://dx.doi.org/10.17763/haer.63.2.t875w42q30w8qk04

Gehring, T. (2016). Current prison reform initiatives: It's time to remember forgotten lessons. San Bernardino, California: California State University. (Unpublished manuscript).

Greene, M. (1995). Releasing the imagination: Essays on education, the arts, and social change. San Francisco: Jossey-Bass.

Merleau-Ponty, M. (1962). Phenomenology of perception. London: Routledge.

Weiss, G. (2006). Urban flesh. In Olkowski, D. \& G. Weiss (Eds.), Feminist interpretations of Maurice Merleau-Ponty. University Park: Pennsylvania State University Press.

Wright, R. (2008). Metaphors of experience-the prison teacher as stranger. In Wright, R., (Ed.), In the borderlands: Learning to teach in prisons and alternative settings. San Bernardino, California: California State University San Bernardino Press.

Yantz, S. (2008). Borderland negotiations: Re-presentation of identity as a prison educator. In Wright, R., (Ed.), In the borderlands: Learning to teach in prisons and alternative settings. San Bernardino, California: California State University San Bernardino Press.

G. Walker is a doctoral student in the School of Education at Virginia Commonwealth University. 